\title{
Science in Australia: alive, well, kicking, and growing
}

\author{
Richard Smith
}

In the past few years the Australian government has "got science" in the way that some people get religion. Research has ceased to be seen as a drain on the public purse and is now viewed as the engine of the future economy. Fear of being shut out of foreign markets and recognition of the vulnerability of depending so much on agricultural products and natural resources gave rise to the "clever Australia" policy that was pushed by the Labor party in its election campaign in early 1990 (fig 1). Australia will compete on brains, not muscle and minerals. These ideas together with sophisticated campaigning by scientists (see first two boxes) have led to science being given more prominence.

Health research has not been at the centre of the debate because it has done better than other sectors. While Commonwealth funding of research in sectors other than health was stable or even fell in real terms during the ' $80 \mathrm{~s}$ the funding of health research increased (fig 2). ' This is a tribute to the "medical mafia" fighting their corner (usually by personal contact) and to the Australian Society for Medical Research, a "young turks" organisation that has campaigned tirelessly and effectively for medical research (see second box).

In November I visited Australia to look at the organisation and funding of medical research in general and at the unique Australian institutes in particular. I travelled to Sydney, Canberra, Melbourne, Adelaide, and Brisbane; visited seven institutes (including all those with block grants); and met the Minister of Health, the present and immediate past chairpersons

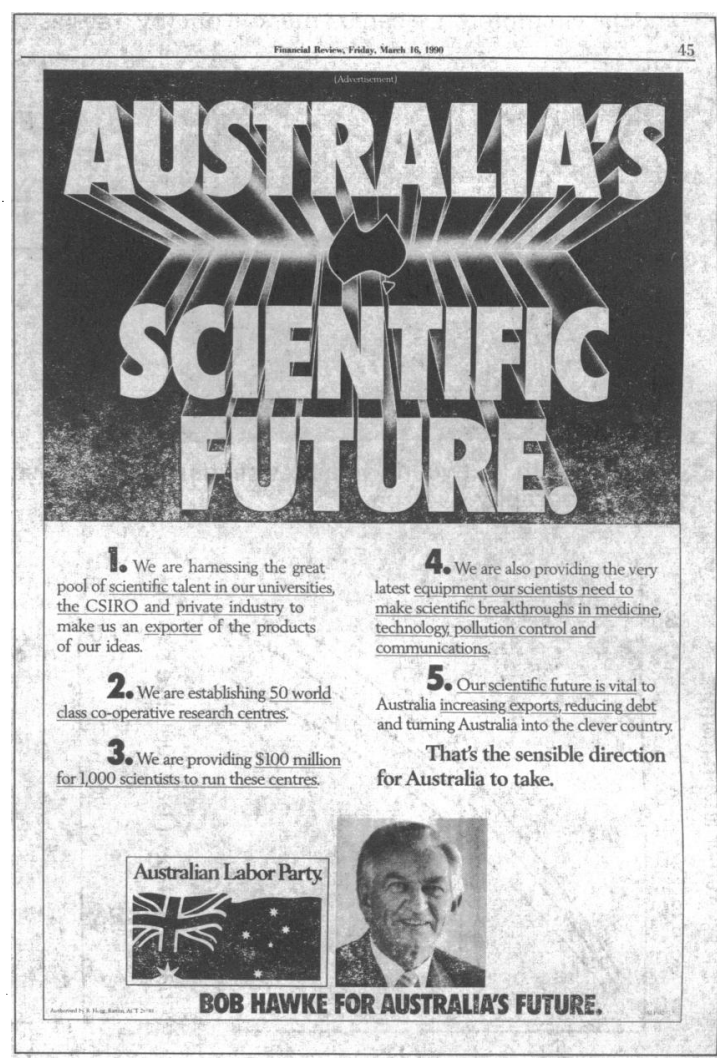

FIG 1-Poster used by Labor party in general election of 1990

\section{Saving Australian science}

The Australian pressure group for science-the Federation of Australian Scientific and Technological Societies (FASTS) - has had success in arguing the case for more resources for science. Science became an important issue in the general election in 1990, and the government announced that it would spend what would eventually become $\$ A 100 \mathrm{~m}$ a year on cooperative research centres (see third box). The government has changed from thinking of science as a luxury - like opera - to thinking of it as an essential investment for Australia's future. FASTS was important in bringing about that change.

FASTS was started at the prompting of the Australian Academy of Science (the equivalent of the British Royal Society) after the 1984 budget had been particularly savage for science. Dr David Widdup, the full time executive director of FASTS, told me that he calls the organisation "the provisional wing of the academy." The federation links together some $60-70$ professional scientific societies, all of which pay a levy. The director thus does not have to worry about funding, and his budget is about $\$ A 100000$ a year. The federation has a loose structure but makes sure that all the various interest groups have their say: "But sometimes," says Dr Widdup, "groups will fade away when the going gets politically tough and reappear when peace breaks out." Altogether some 60000 scientists are represented by FASTS.

FASTS is politically more sophisticated than its amateurish British counterpart, Save British Science. Much of this must be put down to Dr Widdup, who as well as being trained as a mathematician is a lawyer who
British Medical Journa London WC1H 9JR Richard Smith, MB, executive editor

BMF 1991;302:840-2 worked for the Attorney General. He understands how politics works in Australia and knows personally many ministers and several shadow ministers. "The turning point in our cause," he says, "was when we made the economic case that science was vital for Australia." But also crucial has been targeting the Prime Minister, who was, for instance, shocked and surprised to be pelted with scones by scientists when opening a prestigious scientific centre in Canberra.

FASTS has also made great use of the media: last year it put out some 50 press releases, only two of which failed to make a story. "And," says Dr Widdup, "one story is enough, for the cutting service will make sure it's on the minister's desk." Another factor in the federation's success was that it understood the sophisticated electioneering used by the Labor party, which has governed Australia for many years. It has identified opinion formers at a very local level, and these people are targeted with information from the party. FASTS threatened in the last election to use its grassroots organisation-which includes, for instance, science and mathematics teachers all over Australia - to create new local opinion formers, throwing the party's "marketing" into chaos.

Other science pressure groups around the world should look closely at how FASTS has worked because it has been more successful than many. The science minister has acknowledged how the federation turned round the government's view on science, and two independent polls have shown that between $80 \%$ and $90 \%$ of Australians favour more investment in scientific research. 


\section{Stronger together: the Australian Society for Medical Research}

Medical research depends on the young because they supply most of its people and new ideas, and yet the young often have little power within the systems that run medical research. Recognising these factors and inspired by the "young turks" of the American Federation for Clinical Research, young Australian researchers founded the Australian Society for Medical Research in 1961. With 1100 members and run by directors who must be under 40 , the society is now a key player in Australian medical research - not least because many of its former presidents and directors are running the research establishment.

One of the primary concerns of the society is career development. Each year the society holds a national meeting that about 250 members attend, and young researchers make their first presentations within this supportive environment. Career advice is also provided, and there are workshops on issues like how to make a presentation and how to write a grant proposal. The society makes submissions to the National Health and Medical Research Council on what it sees as shortcomings within the research career structure; it also takes up particular issues like the inadequacies of the career structure for women in research.

The second and most important function of the society is to impress on the public the human and economic importance of medical research. Each year it organises a medical research week, and the branches within each state organise a series of functions. Thus one year the South Australia branch set up displays within shopping malls; ran a health fair that attracted about 5000 people; held a schools' art competition and a schools' day with the Science Teachers' Association; and had a lobbying dinner for about 200 community leaders, politicians, businesspeople, and journalists. The week gained wide coverage in the media. Although it was exhausting for the researchers, all of those I met were convinced that this was time, money, and energy well spent: young people are attracted towards a career in research, public support and understanding are increased, money is raised, and ultimately pressure is put on politicians to fund medical research generously.

The society also engages in more behind the scenes political action. Members within each state make it their business to court key ministers, and every year some of the national office holders make a pilgrimage to Canberra and meet the ministers of health, science, education, and higher education. The public affairs committee of the society (its political wing) is one of the areas where those over 40 help, and the campaigning strategy is different from that of the Federation of Australian Scientific and Technological Societies. The medical researchers operate in a more low key but no less effective manner: thus they will "send a Greek researcher to talk to a Greek minister or MP" and they will concentrate on the human benefits of medical research. Who can refuse to fund research that might cure childhood leukaemia or reduce deaths from heart disease? of the National Health and Medical Research Council and the Medical Research Committee, the immediate past president of the Australian Academy of Sciences, several of the "medical mafia," and many other people who will be listed at the end of the last article in this series. All were friendly and open in a way that many of the British cannot emulate, and I am grateful to them all.

This first article in a series of four examines Australian science in general; the next will look at how health research is organised and how the National Health and Medical Research Council sets its strategy and priorities; the third will consider some of the detailed workings of the National Health and Medical Research Council; and the last will concentrate on the institutes.

\section{The May statement}

A recent highpoint in Australian science was the statement made in May 1989 by Bob Hawke, the Prime Minister, and Barry Jones, then Minister for Science. ${ }^{2}$ The two men laid out a strategy for Australian science

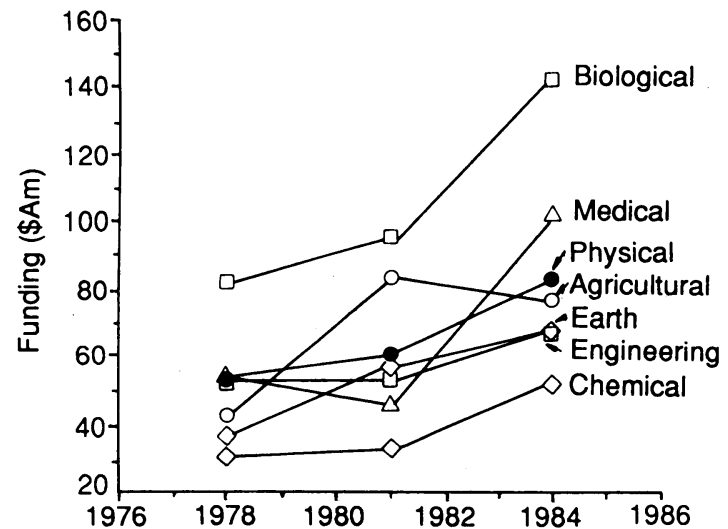

FIG 2-Funding of medical and other categories of research in Australia, 1976-84 and made a firm commitment to its importance. They said:

The recognition that science and technology play a central role in achieving national objectives is fundamental. It is from this recognition that the attention given by government flows. At its most general this involves acknowledging that economic and social development in the modern world is dominated by science and technology and its approach to problems, and no government can do other than to give it a central place.

After making this commitment the ministers announced a four part strategy for science and technology (table). ${ }^{2}$ Increased funding is part of the

Australian government's four part strategy for science

1: Central role of science and technology in achieving national objectives Government recognition of the essential role of science and technology in a diverse range of activities

2: Management strategy

Promoting links between research and users

Pursuit of excellence

Increase in overall funding of research and development

3: Human resources strategy

Creativity

Training

4: Science and technology and the wider community

strategy, and the ministers acknowledged that "decades of neglect and insufficient funding have led to a rundown in science and technology infrastructure." The government is keen that much of the new funding should come from industry. When compared with other developed countries Australia doesn't do badly in comparisons of government funding, but business funding is particularly low (fig 3). ${ }^{1}$ The government wants to achieve the position where $2 \%$ of its gross domestic product is spent on research, which means that industry needs to more than double its expenditure. One important part of the government's science strategy is the $\$ S A 100 \mathrm{~m}$ a year it eventually wants to be spending on cooperative research programmes in which researchers must link up with "end users" to achieve industrial, health, or environmental ends 


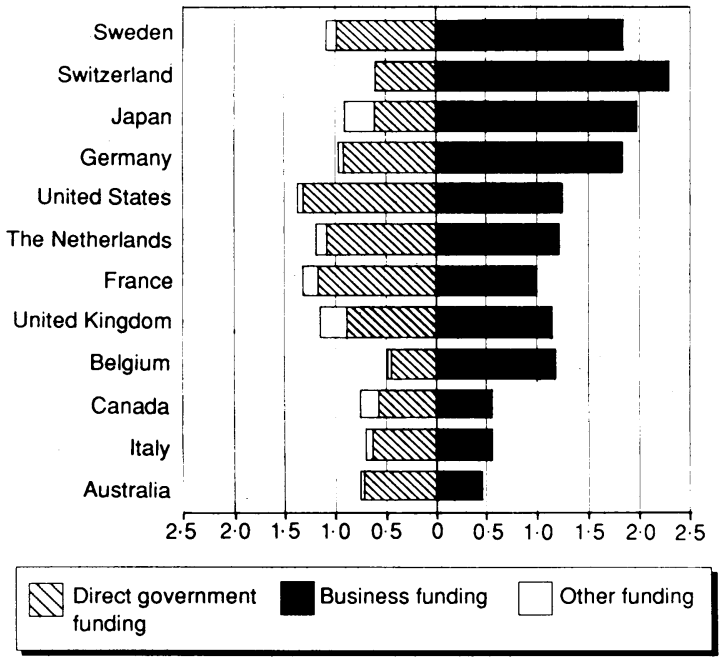

FIG 3-Public and business funding of science as percentage of gross domestic product in selected developed countries

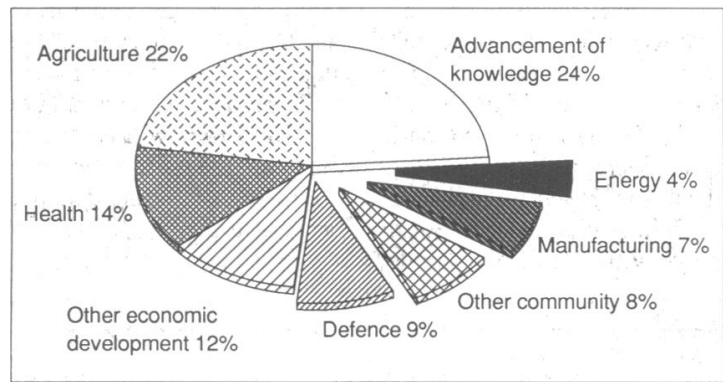

FIG 4-Public expenditure on science in Australia by sector, 1986-7 (total expenditure was approximately $\$ A 2000 m$ excluding business enterprises)

(third box). ${ }^{3}$ The government wants more mission oriented research, although the two ministers called it "a dangerous fallacy ... that research must be required to meet utilitarian goals."

One important aim of the strategy is to "raise the level of scientific and technological literacy in our community." The government is pushing science and maths in schools, and the proportion of students completing more than 12 years of education increased from $38 \%$ in 1982 to $52 \%$ in 1990 . The government has also launched a programme of broadening university education, and one part of this is to convert all institutions of further education into universities (a

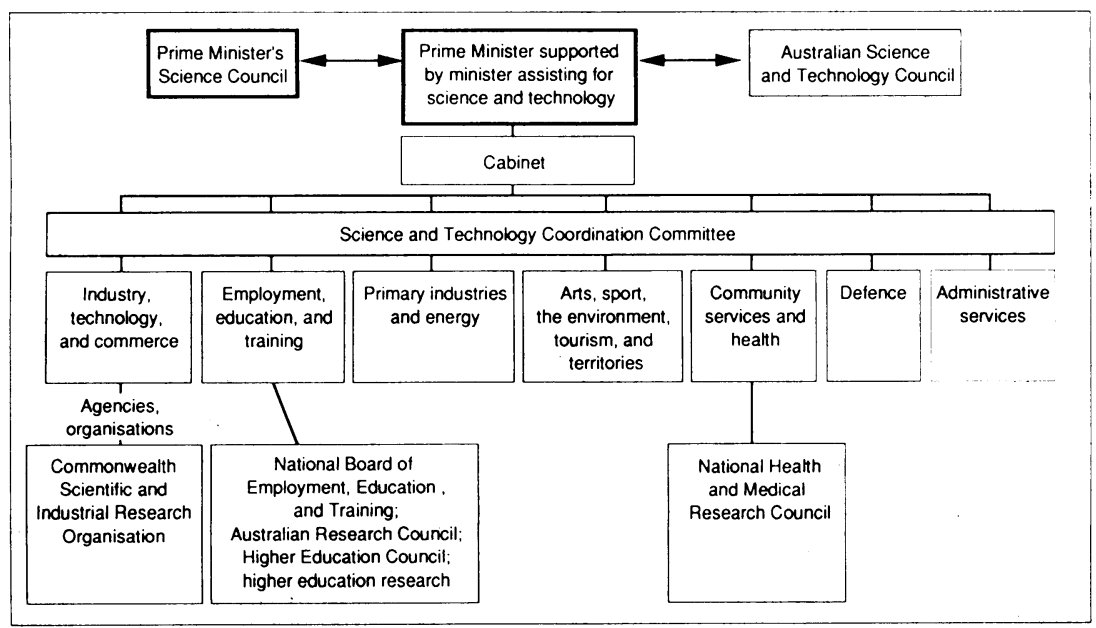

FIG 5-Organisation of science and technology in Australia

\section{Cooperative research centres}

The most direct result of the Australian government "getting science" has been the setting up of the cooperative research centres programme, which will be built up until it has funds of $\$ \mathrm{~A} 100 \mathrm{~m}$ a year by 1994-5. Australian industry has a poor record in research and development, and the central aim of the programme is to link public and private research. It will build on existing research strengths, achieve some concentration of research, and stimulate education and training. The government is keen that the programme should lead to new research and not just be another source of funds for existing research.

Some 100 applications were received from combinations of research institutions and "end users" of research, among them various groups doing medical research, and about 15 are to be funded in the first year.

plan mooted in Britain in the past week). This move has horrified some of the older universities, and they resent too the direction of university affairs and the squeezing of resources that has come from the Minister for Employment, Education, and Training, John Dawkins. Most of the researchers I met in Australia were worried about the state of the universities.

Figure 4 shows where the money goes, ${ }^{2}$ and figure 5 shows the present organisation of science and technology in Australia. Points to note are that the Prime Minister is taking direct responsibility for science; research funds flow down through a great many departments; and, compared with in Britain, defence research is unimportant and agricultural research is more important. The crucial feature in relation to health is that the National Health and Medical Research Council is linked with the Department of Health and Community Services rather than with the Department of Employment, Education, and Training, as is the Australian Research Council, the body that funds non-health research.

\section{Conclusions}

The language that the Australian government speaks when talking of science comes from scientists. Australian scientists after a hard struggle have got their message through to the government by a combination of professionalism, sophistication, and persistence. One factor that has been particularly important has been the economic argument. British scientists could learn a lot from the Australians.

This is the first of four articles.

1 Australian Science and Technology Council. Profile of Australian science. Canberra: Australian Government Publishing Service, 1989.

2 Hawke RJL, Jones BO. Science and technology for Australia. Canberra: Australian Government Publishing Service, 1989

3 Cooperative Research Centres Committee. Cooperative research centres program. Canberra: Australian Government Publishing Service, 1990.

\section{Correction}

Everyday aids and appliances: leisure and recreation

An editorial error occurred in this article by Dr E White $(23$ February, $p 461$ ). The telephone number of the Disabled Living Foundation was given incorrectly; it is 0712896111 . In addition, no address was given for the disabled living centres, which offer specialist advice; they can be contacted through the Disabled Living Centres Council, 380 Harrow Road, London W9 2HU (tel $0712662059)$. 